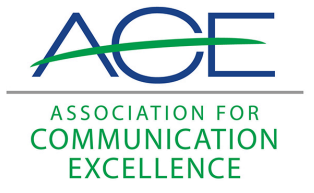

Journal of Applied Communications

\title{
Managing Media Relations: Determining the Reputation of Land Grant Institutions from the Perspective of Media Professionals
}

Lauri M. Baker

Katie Abrams

Tracy Irani

See next page for additional authors

Follow this and additional works at: https://newprairiepress.org/jac

(c) (i) (9)

This work is licensed under a Creative Commons Attribution-Noncommercial-Share Alike 3.0 License.

\section{Recommended Citation}

Baker, Lauri M.; Abrams, Katie; Irani, Tracy; and Meyers, Courtney (2011) "Managing Media Relations: Determining the Reputation of Land Grant Institutions from the Perspective of Media Professionals," Journal of Applied Communications: Vol. 95: Iss. 2. https://doi.org/10.4148/1051-0834.1180

This Research is brought to you for free and open access by New Prairie Press. It has been accepted for inclusion in Journal of Applied Communications by an authorized administrator of New Prairie Press. For more information, please contact cads@k-state.edu. 


\title{
Managing Media Relations: Determining the Reputation of Land Grant Institutions from the Perspective of Media Professionals
}

\author{
Abstract \\ In recent years, the land grant university has struggled with public awareness outside of its traditional \\ audiences, indicating a potential disconnect between the general public and the media. The purpose of \\ this study was to assess the perceptions and awareness of media with regard to the image and \\ reputation of the University of Florida's Institute of Food and Agricultural Sciences (UF/IFAS). A sample of \\ 150 state and local media professionals was surveyed to assess perceptions and awareness of UF/IFAS. \\ The results indicated that the media's perceptions of UF/IFAS image and reputation were positive, but \\ their awareness of the institution's range of program areas was low. Media professionals consider the \\ information provided by UF/IFAS to be credible, useable, and newsworthy. Respondents said the \\ environment, followed by disaster preparation and recovery were the most important topics to their target \\ audience, while the least important topics to their target audience were 4- $\mathrm{H}$ youth development and \\ agriculture. Media professionals were more likely to use UF/IFAS as a source for agriculture and natural \\ resource topics than other topics. Other universities should consider conducting similar research to \\ develop a body of knowledge on media relations at land grant institutions.
}

\section{Keywords}

f UF/IFAS, public awareness, credible, Media professionals, newsworthy, land grant institutions, universities

\section{Authors}

Lauri M. Baker, Katie Abrams, Tracy Irani, and Courtney Meyers 


\title{
Managing Media Relations: Determining the Reputation of a Land Grant Institution from Perspective of Media Professionals
}

\author{
Lauri M. Baker, Katie Abrams, Tracy Irani, and Courtney Meyers
}

\section{Abstract}

In recent years, the land grant university has struggled with public awareness outside of its traditional audiences, indicating a potential disconnect between the general public and the media. The purpose of this study was to assess the perceptions and awareness of media with regard to the image and reputation of the University of Florida's Institute of Food and Agricultural Sciences (UF/IFAS). A sample of 150 state and local media professionals was surveyed to assess perceptions and awareness of UF/IFAS. The results indicated that the media's perceptions of UF/IFAS image and reputation were positive, but their awareness of the institution's range of program areas was low. Media professionals consider the information provided by UF/IFAS to be credible, useable, and newsworthy. Respondents said the environment, followed by disaster preparation and recovery were the most important topics to their target audience, while the least important topics to their target audience were 4-H youth development and agriculture. Media professionals were more likely to use UF/IFAS as a source for agriculture and natural resource topics than other topics. Other universities should consider conducting similar research to develop a body of knowledge on media relations at land grant institutions.

\section{Introduction}

The mission of the land grant university is to provide education, research, and public outreach (extension) for the citizens in its state. Traditionally, the role of transferring the research information and technology generated via the land grant and its tripartite mission has fallen to the Cooperative Extension Service. The Smith-Lever Act of 1914 created extension to assist in diffusing useful and pragmatic information to the people of the United States (Rasmussen, 1989). Since the early $19^{\text {th }}$ century, however, face-to-face transfer of information from the land grant has been augmented by mediated channels of communication, ranging from print and broadcast media to the Web. In response to the need to communicate effectively using multiple channels, land grants have developed "communications service units" staffed by public information specialists, writers, and videographers, whose job it is to help shape communications and information/education efforts. In county extension offices, agents contribute to this trend by increasingly making use of local media to promote their programs and events (Telg, Irani, Hurst, \& Kistler, 2007), and in many cases are able to reach larger audiences through local newspaper columns, public affairs shows, Web sites and the like. While some of this communication is placed as advertising, the vast majority is targeted toward media outlets in the form of press releases, public service announcements, features, and news stories (2007). Although the literature has focused on land grant communications from the marketing and 
branding standpoint, little research exists that looks at the effectiveness of land grant public relations in general, and media relations in particular.

The modern land grant institution faces many challenges to define itself in terms of new and non-traditional audiences for its services. As more Americans move away from rural areas and agricultural production systems, land grants have kept up with the pace of societal changes by diversifying program areas to better serve urban and suburban citizens. Today, in addition to agriculture, land grant program areas are targeted to include the environment, families and consumers, home horticulture, sustainable living, disaster preparation and recovery, and youth development. As these institutions have diversified in terms of program areas and stakeholder demographics, however, awareness and understanding of the land grant mission has dwindled (Kellogg, 1999).

In response to decreased awareness and potential budget cuts, land grants have scrambled to demonstrate their value and accountability through the name branding and marketing of their services. For example, the University of Florida brands itself as the Institute of Food and Agricultural Sciences, or "IFAS", which was conceived in 1964 to demonstrate the link between the three parts of the land grant mission. Other land grant institutions have also created a brand name to develop a brand identity and establish an institutional reputation with new and existing publics. Oklahoma State University, for example, has its Division of Agricultural Sciences and Natural Resources (DASNR), Texas A\&M University has AgriLIFE, and Louisiana State University has the AgCenter. Land grant branding is intended to mirror corporate marketing communication models by creating a brand to differentiate services and generate memorability and preference. But, given the lack of budgetary resources needed to generate brand awareness through marketing mechanisms, sole reliance on these efforts is likely to be of limited effectiveness without an approach that leverages the potential impact of public relations.

\section{Literature Review}

\section{Excellence in Public Relations Theory}

Certainly, public relations and marketing are both essential to organizations, but public relations scholars argue that although they may be complementary, they are separate functions, each bringing distinct perspectives to an organization (Grunig \& Grunig, 1998; Grunig L. A., 1997). When either public relations or marketing is emphasized more than the other, the organization may "end up 'speaking with one voice' (often a rationale for integrating marketing, advertising, and public relations), but it is able to listen with only one ear" (Grunig L. A., 1997, p. 291). Marketing primarily focuses on one-way communication, supplemented with two-way communication that occurs only with customers or clients. Effective public relations involves developing relationships not only with clients, but also with strategic constituents, called "publics," such as governmental agencies, the mass media and trade presses, financial publics, the employees, and special interest or activist groups (1997). This description suggests that the ideal foundation of public relations is, and should be, rooted in two-way symmetrical communication between the organization and its publics. However, this is difficult to achieve, especially in the instance of public relations efforts on behalf of public institutions such as land grants because of the large amount of people involved in communication efforts, often in multiple locations throughout the state.

Grunig and Hunt (1984) defined four models of public relations-press agentry; public information; two-way asymmetrical and two-way symmetrical. The two most relevant models to this study are the public information model and the two-way symmetrical model. The public information 
model is characterized by the use of press releases and other one-way communication techniques to distribute organizational messages through in-house journalists. The two-way symmetrical model uses research with publics to facilitate understanding and communication, whereas a two-way asymmetrical model (highly characteristic of marketing) uses research to determine the messages most likely to persuade publics (as cited in Grunig \& Grunig, 1992). The long-standing assertation in the field of public relations posited by Grunig and Grunig is that "organizations should practice twoway and symmetrical communication when their environments are complex and turbulent" (p. 298).

Because land grant institutions are public sector organizations with multi-faceted goals (teaching, research, and extension) and extremely diverse stakeholder groups, they are naturally inclined to rely more on the public information model. However, to improve outreach and increase accountability, as recommended by the Kellogg Commission (1999), land grant universities may need to more fully embrace two-way communication approaches based on needs-assessments with publics and issues-based program development (Donnellan \& Montgomery, 2005).

\section{Media Relations}

A critical function of public relations is maintaining good relationships with relevant media organizations. Organizations utilize public relations in order to leverage the credibility of the news media to target publics with messages that promote goodwill. "Good press" arises as a result of an organization's engaging in media relations activities that enhance the potential for positive coverage in the news media. Schenkler and Herrling (2003) stated that these types of media relations efforts are vital for two reasons. The media can affect an organization's reputation positively or negatively. The reputation of an organization formed and held in memory by a stakeholder as informed through the media "serves as the 'reality' of the organization for that individual" (Brown, Dacin, Pratt, \&Whetten, 2006, p. 105). Additionally, the media can be the most direct and available channel to reach clientele, influence the opinions of legislators, motivate employees, and enhance/defend organizational reputation (Schenkler \& Herrling, 2003). Conversely, while working to establish a strong reputation, an organization should also consider ways to enhance their brand name and credibility (Fill, 2002). Media professionals certainly desire to be viewed as credible, and thus consider the credibility of their sources when crafting a story. If they tie source credibility to a specific organization's brand name and reputation, they may return to that organization for credible information in the future.

Effective media relations involves knowing and anticipating the needs of the media. Media professionals have numerous "feelers" out to capture and convey information of interest to their target audiences. They speak with co-workers and trusted sources, observe news wires, and sort through numerous press releases (Schenkler \& Herrling, 2003). "In theory, journalists and sources have a symbiotic relationship: sources require journalists to get their views or ideas into the news, while journalists require sources for direction, clarification, context, perspective, and commentary. In reality, ... journalists rely more on sources than vice versa" (Conrad, 1999, p. 286). Historically, journalists have mistrusted public relations practitioners as sources, deeming that they selfishly push the goals of their respective organization or conceal negative information (Ryan \& Martinson, 1988). To build positive relationships with the media, organizations must be honest and open, provide accurate information, be responsive and timely, reliable and consistent, and prepared (Desiere \& Bey-Ling, 2007).

\section{Purpose \& Objectives}

The potential media relations problem for land grant institutions is not that they do not have the 
characteristics recommended by Desiere and Bey-Ling (2007), but the media, like other stakeholder groups, may not be aware of the functions and range of issues covered by these institutions. The purpose of this study was, therefore, to assess the perceptions and awareness of media with regard to the image and reputation of a land grant, the University of Florida's Institute of Food and Agricultural Sciences (UF/IFAS). This institution was chosen for two reasons. First, UF/IFAS has engaged in a recent multi-year effort to improve its brand image and identity using primarily corporate marketing techniques (Meyers, Irani, \& Eckhardt, 2006). Secondly, the data in this study was part of a larger data collection effort that assessed perceptions of brand image and awareness of producers and community leaders (Chodil, Meyers, Irani, \& Baker, 2008). Although data was collected on some items common to all three groups, media professionals were additionally asked specific items related to source credibility and information channel preferences with a view toward understanding how these perceptions could potentially shape the media relations dynamic. Based on the above, the following research objectives were developed to guide this study:

- Determine state media professionals' awareness of UF/IFAS and its teaching, research, and extension components;

- Determine state media professionals' preferred source and information channels with respect to agricultural and natural resources related news;

- Investigate state media professionals' perceptions of UF/IFAS as an information source.

\section{Methodology}

A descriptive telephone survey methodology was utilized to determine levels of awareness and perceptions of state media professionals. The sampling frame was developed to collect data from representative samples of media professionals statewide based on the type of media outlet in which they were employed. Lists of names were developed from several existing data sources and then sampled using a stratified random sampling technique. These data sources included multiple lists of media contacts and purchased media directory listings for print and broadcast news media.

This study utilized computer assisted telephone survey methodology to collect data from the samples. Interviews were conducted by the University of Florida's Survey Research Center using the CATI system. Trained telephone interviewers followed a researcher-developed questionnaire. Interviewers read the questions directly from the computer screen to ensure consistency. Interviewers contacted the media representatives between the dates of December 17, 2007, and January 9, 2008. There were 460 media professionals in the sample and 1527 calls were made, including up to six callbacks. The media professionals who completed the survey totaled 150 for a response rate of $32.6 \%$.

To conduct the study, a 25-item survey questionnaire was developed using questions from previous surveys of UF/IFAS stakeholders and a national study of extension awareness (Warner, Christenson, Dillman, \& Salant, 1996; Chodil et al., 2008). Items included a series of questions focusing on awareness and perception of UF/IFAS. Questions were also asked regarding the image and reputation of UF/IFAS, and preferred method of receiving information. The instrument was reviewed prior to being implemented by a panel of experts, which included representative media professionals who were not part of the survey population, for face and content validity. The instrument took into consideration the uniqueness of the media and their interactions with their target audience to adapt the questions for this audience. Data were analyzed in SPSS 16.0 to generate descriptive frequencies and means. 


\section{Media Demographics \\ Media Professionals}

The majority of the media professionals were male $(58.7 \%, n=88)$ and white $(90.7 \%, n=136)$. The average age of study participants was 46 . The majority of respondents $(58 \%, n=87)$ attained a four-year bachelor's degree. The next highest percentage $(19.3 \%, n=29)$ attained a graduate/professional degree. Nearly $17 \%(16.7 \%, n=25)$ of respondents were University of Florida alumni. Only $2 \%$ of the media professional were alumni from the university's College of Agricultural and Life Sciences.

\section{Organizational Characteristics}

The media professionals surveyed worked for a variety of types of media, and in some cases, for more than one type of media outlet (which caused the following percentages to total greater than $100 \%)$, with the largest percentage working for a newspaper at $74 \%(n=111)$ and the smallest percentage working in radio $(7.3 \%, n=11)$. Nearly half of the respondents worked for an online publication $(48 \%, n=72)$. Approximately $15 \%$ worked for a magazine $(16.7 \%, n=25)$ or a television station $(14.7 \%, n=22)$. The circulation size of the print media ranged from 1,800 to 700,000 (median=12,000). The majority of the printed publications were printed either daily or weekly at $66 \%$ $(n=99)$. The online publications had from 5 to 7,000 users, although only $4 \%(n=6)$ of the online publications required a membership to view them. Radio listeners ranged from 70,000 to 25,000,000 (median=110,000) and television viewers ranged from 36,000 to 596,000 (median=130,000). The primary coverage area of the media was either city or urban, which totaled $50 \%(n=75)$ and the smallest coverage area was suburban at $6.7 \%(n=10)$ (see Table 1$)$.

\section{Table 1}

Primary Coverage Area of Media Respondents

\begin{tabular}{lcc}
\hline & $n$ & Percent (\%) \\
\hline Rural & 29 & 19.3 \\
Small town & 26 & 17.3 \\
City & 33 & 22.0 \\
Urban & 42 & 28.0 \\
Suburban & 10 & 6.7 \\
Don't know & 6 & 4.0 \\
Refused & 4 & 2.7 \\
\hline Total & 150 & 100 \\
\hline
\end{tabular}

\section{Results}

Objective One: Determine state and local media professionals' awareness of UF/IFAS and its teaching, research, and extension components

Respondents were asked a series of questions to determine their level of awareness of the University of Florida, then UF/IFAS, and finally the program areas on which UF/IFAS focuses. The 
majority of media respondents $(58.7 \%, n=88)$ were either very or somewhat familiar with UF/IFAS' research, education, and extension work. When asked how many times in the past six months they covered a story in which they used UF/IFAS as a source, $43.3 \%(n=65)$ said they used UF/IFAS as a source between one and seven times. Ten percent $(n=21)$ said they used UF/IFAS as a source 10-24 times in the past six months.

When respondents were asked how generally informed they were about the research, education, and public service activities of the University of Florida, the majority, 58.7\% $(n=88)$ reported they were either somewhat or very informed. However, when asked unaided (not given a list of choices) what organizations in Florida conduct research and/or provide information about food, agriculture, and natural resources, only $14.7 \%(n=22)$ of media said the Institute of Food and Agricultural Sciences.

If respondents did not mention UF/IFAS unaided, they were then prompted as to if they had ever heard of UF/IFAS or the University of Florida's Institute of Food and Agricultural Sciences. This resulted in a greater percentage of awareness, with $35.3 \%(n=53)$ of media indicating they had heard of UF/IFAS.

Respondents who expressed aided awareness of UF/IFAS $(35.3 \%, n=53)$ were then asked on what program areas UF/IFAS focuses (see Table 2). The greatest level of awareness was of agriculture and lawn and garden program areas.

\section{Table 2}

Media Respondents' Awareness of UF/IFAS Program Areas (Unaided)

\begin{tabular}{lcc}
\hline Topic & $n$ & Percent (\%) \\
\hline Agriculture & 74 & 49.3 \\
Lawn \& Garden & 27 & 18 \\
Environment & 19 & 12.7 \\
Families \& Consumers & 20 & 13.3 \\
4-H Youth Development & 5 & 3.3 \\
Sustainable Living & 12 & 8 \\
Disaster Preparation \& Recovery & 3 & 2 \\
Other/Don't Know & 15 & 10 \\
\hline
\end{tabular}

The media respondents were then asked how they cite people or information related to UF/ IFAS when used as a source. Only $8.7 \%(n=13)$ said they typically cite the brand acronym UF/IFAS alone. Thirty percent $(n=45)$ said they used the full name, University of Florida Institute of Food and Agricultural Sciences. The remaining respondents said "other" at 27.3\% $(n=41)$ or don't know $(2.7 \%, n=4)$ (see Table 3$)$. The majority of the responses in the "other" category said they used both the acronym and the full name together or just the University of Florida. 
Table 3

How Media Respondents Cite Information from UF/IFAS (Unaided)

\begin{tabular}{lcc}
\hline & $n$ & Percent (\%) \\
\hline UF/IFAS (Acronym) & 13 & 8.7 \\
University of Florida Institute of Food and & 45 & 30.0 \\
Agricultural Sciences (full name) & & 27.3 \\
Other & 41 & 2.7 \\
Don't Know & 4 & \\
\hline
\end{tabular}

\section{Objective Two: Determine media professionals' preferred source and information channels with respect to agricultural and natural resources related news}

In order to assess this objective, media professionals were read a list of various communication channels for receiving information, and were asked their preferred method, followed by their second preferred method, and then their third preference. An overwhelming majority of the media professionals preferred to be contacted by e-mail $(86 \%, n=129)$, followed by phone $(7.3 \%, n=11)$. Fax $(2 \%$, $n=3)$, mail $(2 \%, n=3)$, and Web $(2 \%, n=3)$ as the next preferred choice; these were all of equal preference. The second preferred method of receiving information were more diverse. Fax $(32 \%, n=48)$ was the first of the second preferred, followed closely by Web at 27.3\% ( $n=41)$. See Table 4 below.

\section{Table 4}

Media Professionals' Preferred Information Channels (Aided)

\begin{tabular}{lcccccc}
\hline & \multicolumn{2}{c}{ Preferred Method } & \multicolumn{2}{c}{ Second Choice } & \multicolumn{2}{c}{ Third Choice } \\
\hline E-mail & $n$ & Percent $(\%)$ & $n$ & Percent $(\%)$ & $n$ & Percent (\%) \\
Phone & 129 & 86 & 17 & 11.3 & 10 & 6.7 \\
Fax & 11 & 7.3 & 28 & 18.7 & 41 & 27.3 \\
Mail & 3 & 2 & 48 & 32 & 41 & 27.3 \\
Web & 3 & 2 & 10 & 6.7 & 22 & 14.7 \\
Blog & 3 & 2 & 41 & 27.3 & 19 & 12.7 \\
RSS & 1 & .7 & 0 & 0 & 6 & 4 \\
Other & 0 & 0 & 3 & 2 & 6 & 4 \\
Don't Know & 0 & 0 & 2 & 1.3 & 0 & 0 \\
\hline
\end{tabular}

To further assess this objective, media professionals were asked which sources they used to obtain information for news stories or information presentation. The most used source were press releases at $85.3 \%(n=128)$, followed by the AP wire at 50\% $(n=75) .49 .3 \%(n=74)$ of respondents reported use of the University of Florida News and Public Affairs. Nearly 50\% of the media (48\%, $n=72)$ said they use another source; these other sources varied from local primary sources and community contacts to national media groups and/or wire services and commodity organizations (see Table 5). 


\section{Table 5}

Sources Used by Media Respondents (Aided)

\begin{tabular}{lcc}
\hline & $n$ & Percent (\%) \\
\hline AP & 75 & 50.0 \\
UPI & 22 & 14.7 \\
Reuters & 40 & 26.7 \\
RSS Feed & 28 & 18.7 \\
Press Release & 128 & 85.3 \\
UF News \& Public Affairs & 74 & 49.3 \\
Other 1 & 72 & 48.0 \\
Other 2 & 15 & 10.0 \\
Don't Know & 1 & .7 \\
\hline
\end{tabular}

Note. Respondents were read a list of options; "Other 2" was only recorded after a respondent gave a response in "Other 1"; n=number of respondents in each category.

\section{Objective Three: Investigate local media professionals' perceptions of UFIIFAS as an information source}

To assess this objective, respondents were asked a series of questions about information provided by UF/IFAS. Respondents who had used UF/IFAS information in the past indicated they view the information provided by UF/IFAS as credible, useful to their work, and newsworthy for their audience, with credible receiving the highest rating (see Table 6).

Table 6

Media's Opinions of Information Provided by UF/IFAS

\begin{tabular}{lccc}
\hline & $n$ & Mean & SD \\
\hline Credible & 110 & 3.55 & .49 \\
Useful & 116 & 3.22 & .63 \\
Newsworthy & 112 & 3.14 & .58 \\
\hline
\end{tabular}

Note. 1 =strongly disagree, 2 =disagree, $3=$ agree, $4=$ =strongly agree; $n=$ number of respondents for each item, only the participants who had used UF/IFAS information in the past answered this series of questions $(n=116)$.

Media respondents were then read a list of UF/IFAS program areas. Using a scale from 1 to 5 (1=“very unimportant" and 5="very important"), respondents were asked how important the UF/ IFAS program areas are to their target audience. Respondents said the most important program area to their target audience was the environment (4.15). The second most important was disaster preparation and recovery (3.90) and the least important was 4-H youth development (2.91) (see Table 7). 


\section{Table 7}

Media Respondents' Importance of UF/IFAS Program Areas to Their Target Audience (Aided)

\begin{tabular}{lccc}
\hline & $n$ & Mean & $S D$ \\
\hline Agriculture & 141 & 3.58 & 1.31 \\
Environment & 141 & 4.15 & 1.08 \\
Families \& Consumers & 141 & 3.86 & 1.06 \\
Lawn \& Garden & 141 & 3.09 & 1.27 \\
Sustainable Living & 138 & 3.44 & 1.15 \\
Disaster Preparation \& Recovery & 139 & 3.90 & 1.16 \\
4-H Youth Development & 139 & 2.91 & 1.40
\end{tabular}

Note. Scale was from 1 to 5 , where 1 is "very unimportant" and 5 is "very important"; $n=$ number of respondents for each item.

When asked how willing they would be to use UF/IFAS as a source in specific program areas, media respondents indicated they are the least likely to use UF/IFAS as a source for disaster preparation and recovery. The media respondents were most likely to use UF/IFAS as a source for agriculture and natural resources programs (see Table 8).

\section{Table 8}

Media Respondents' Willingness to use UF/IFAS as a Source on Specific Program Areas (Unaided)

\begin{tabular}{lccc}
\hline & $n$ & Mean & $S D$ \\
\hline Agriculture \& Natural Resources & 139 & 3.93 & 1.344 \\
Families \& Consumers & 139 & 3.04 & 1.356 \\
Disaster Preparation \& Recovery & 137 & 2.71 & 1.456 \\
Sustainable Living & 134 & 3.07 & 1.358 \\
\hline
\end{tabular}

Note. Scale was from 1 to 5 , where 1 is "not at all likely" and 5 is "very likely"; n=number of respondents for each item.

In order to further assess media professionals perceptions of UF/IFAS' image and reputation, respondents who were familiar with UF/IFAS were asked to list three words that best describe UF/IFAS. In accordance with Glaser's constant comparative method, categories were created and grouped according to themes based on responses (Glaser, 1965). Seventy-three media representatives provided at least one word or phrase. All responses were positive in nature. The largest number of responses fell into the category of positive image responses. Common responses were "consumer friendly," "informative," and "agriculture."These responses are analyzed in Table 9 on the next page. 
Table 9

Media Responses When Asked for Three Words that Best Describe UF/IFAS

\begin{tabular}{|c|c|c|}
\hline Response Category & Examples of Answers & $\begin{array}{l}\text { No. of Responses } \\
\text { in Category }\end{array}$ \\
\hline $\begin{array}{l}\text { Positive Image } \\
\text { Responses }\end{array}$ & $\begin{array}{l}\text { informative, competent, knowledgeable, professional, } \\
\text { respected, accurate, facility, attentive, leadership, } \\
\text { leading institute, dedicated, classic, cutting-edge, } \\
\text { connected, dynamic, convenient, expert, enlightened }\end{array}$ & 85 \\
\hline $\begin{array}{l}\text { Education } \\
\text { Responses }\end{array}$ & $\begin{array}{l}\text { education, educational, academic, dedication to } \\
\text { education, authoritative }\end{array}$ & 20 \\
\hline Research Responses & $\begin{array}{l}\text { research, research institute, experimental, researched, } \\
\text { scientific }\end{array}$ & 20 \\
\hline $\begin{array}{l}\text { Positive Need } \\
\text { Responses }\end{array}$ & resource, useful, important, helpful, necessary & 17 \\
\hline $\begin{array}{l}\text { Agriculture \& Food } \\
\text { Responses }\end{array}$ & agriculture, food, citrus, O.J., agricultural & 12 \\
\hline $\begin{array}{l}\text { Positive Emotive } \\
\text { Responses }\end{array}$ & $\begin{array}{l}\text { excellent, great, consumer friendly, personable, good } \\
\text { people, good, very good, self promoting in the best } \\
\text { sense }\end{array}$ & 10 \\
\hline $\begin{array}{l}\text { Community \& } \\
\text { Service Responses }\end{array}$ & $\begin{array}{l}\text { community oriented, public service, local, grass roots, } \\
\text { public interest, helping the community with ag issues }\end{array}$ & 9 \\
\hline $\begin{array}{l}\text { Outreach } \\
\text { Responses }\end{array}$ & outreach & 4 \\
\hline $\begin{array}{l}\text { Communication } \\
\text { Responses }\end{array}$ & media savvy, media, spread message well & 4 \\
\hline $\begin{array}{l}\text { Negative Monetary } \\
\text { Responses }\end{array}$ & under funded, worried about funding, fund needing & 3 \\
\hline Lawn \& Garden & plants, garden, Master Gardener & 3 \\
\hline $\begin{array}{l}\text { Extension } \\
\text { Responses }\end{array}$ & extension & 2 \\
\hline
\end{tabular}

\section{Conclusions and Discussion}

The results of this study indicate that, as a land grant institution with a focus on branding its identity, UF/IFAS has a strong image and reputation among those media professionals who are aware of it. However, overall awareness of the institution on an unaided basis among media professionals is low, despite efforts to develop a brand name identity through marketing alone. On the other hand, respondents who were familiar with UF/IFAS did perceive information from UF/IFAS as credible, useable, and trustworthy, which indicates these respondents perceived UF/IFAS as having a positive reputation. In comparison to findings from the study conducted with producers and community 
leaders (Chodil et al., 2008), media respondents were less informed about research, education, and public service activities at UF/IFAS than producer and leader stakeholder groups.

The media professionals surveyed in this study perceived IFAS to be focused on agriculture; yet, the respondents indicated other program areas and information topics that UF/IFAS also covers are seen as more important to their audience. This finding corroborates the previous study with producer and leader stakeholder groups (Chodil et al., 2008). Because effective media relations involves knowing and anticipating the needs of the media (Schenkler \& Herrling, 2003), UF/IFAS should place more emphasis on targeting key messages to media that coincide with the importance of subject areas in media professionals' target audiences.

Despite a recent increase in tropical storm activity and disaster preparation activities by UF/ IFAS, media respondents indicated they are the least likely to use UF/IFAS as a source for disaster preparation and recovery information. This indicates a potential disconnect between what the media thinks UF/IFAS can provide in the way of information and services and what it actually does provide.

The majority of media respondents indicated they would prefer to be contacted by e-mail with news-related information or press releases. The top ranking second preferred method of receiving information was fax, followed closely by Web. Previous research has shown that although the Web has "irreversibly taken a place in the media relations mix used by public relations practitioners" (Hachigian \& Hallahan, 2003, p. 59), media professionals prefer more direct methods of receiving information such as e-mail or fax. Because the preferred information channels of the media professionals surveyed were primarily one-way communication devices, UF/IFAS needs to find a new way of shaping more two-way communications efforts with media professionals. Two-way and symmetrical communication models are ideal for communication between land grant institutions and media professionals because of the ever-changing, complex environment in which the land grant exists (Grunig, 1992).

The qualitative open-ended response answers offer a deeper understanding of the way media professionals view UF/IFAS. Media professionals' responses indicated that their perceptions of UF/ IFAS' image and reputation are positive, but not strongly valenced. Common responses among the media were "consumer friendly," "informative," and "agriculture." The traditional mission of the land grant includes being responsive to the needs of the state; however, extension, which is traditionally the outreach portion of the land grant's mission, was barely mentioned. In fact, "outreach" and "communication" themes were among those themes with the lowest number of responses. The Results of this study are of limited generalizability, based on the population of state and local media professionals from which the sampling frame was drawn and the application context of a single land grant institution as the focus of the study. However, the findings do suggest limited transferability and some potential future directions for research in this area with other land grants in other states.

\section{Implications}

Overall, results of this study provided support for the argument that land grants, even those engaged in branding and marketing efforts, can stand to gain from leveraging the impact of public relations. Strategically developing strong, positive relationships with the media can build the reputation of the land grant as a credible and trustworthy source of news and information with nontraditional and nonagriculturally based publics. In this study, media professionals saw the land grant as primarily a source for traditional agricultural news and information, and were less likely to be aware of other 
programs areas on which UF/IFAS focuses, including the environment, which respondents rated as being most relevant to their audiences. Developing strategic two-way communications approaches that target state and local media can enhance and potentially extend the reputation of the land grant as serving the interests of all citizens. This "PR problem" represents an opportunity for land grants like UF/IFAS to embrace more of a two-way symmetrical PR model so as to better attune communications about what the land grant does to the needs and interests of the news media's audiences which it intends to serve.

\section{Recommendations}

Recommendations based on the results of this study include recommendations for both theory and practice. From a practitioner standpoint, results of this study suggest the merit of agricultural communicators' developing a two-way communication strategy with media professionals. This strategy should include research to determine the key messages most likely to influence media and their target audiences (Grunig L. A., 1997). Land grant institutions should focus on communicating the programs/topic areas that are of the most importance to key audiences - not what we do, but what has value for our stakeholder audiences, especially those not in traditional production agriculture.

Additionally, land grant institutions should employ the most cost effective communication technologies (examples include Web, search engine optimization, customer relationship marketing) to increase exposure and build impressions with media professionals. This is especially relevant because this and previous research indicates that these communication technologies are the preferred communication channels for media (Irani et al., 2006).

To develop a body of knowledge on media relations at land grant institutions, other land grant institutions should consider conducting similar research. This body of knowledge will open the door for land grant institutions to continue building positive relationships with the media. The focus of these relationships should be on building trust (Fill, 2002) by providing accurate information in a responsive, timely, reliable, and consistent manner (Desiere \& Bey-Ling, 2007). Through continued research and media relations focused communication, land grant institutions' potential "PR problem" can evolve into an admired public relations strategy.

\section{About the Authors}

Lauri M. Baker is an assistant professor in agricultural communications at Kansas State University. Katie M. Abrams is a visiting assistant professor in the Agricultural Communications Program at the University of Illionois. Tracy Irani is a professor in agricultural communication at the University of Florida. Courtney Meyers is an assistant professor in agricultural communications at Texas Tech University.

\section{Keywords}

University image, public relations, university reputation, higher education, media professionals, media relations 


\section{References}

Botan, C., \& Hazelton, V. (2006). Public Relations Theory II. Mahwah, NJ: Lawrence Erlbaum Associates.

Brown, T. J., Dacin, P. A., Pratt, M. G., \& Whetten, D. A. (2006). Identity, intended image, construed image, and reputation: An interdisciplinary framework and suggested terminology. Academy of Marketing Science Journal, 34(2), 99-106.

Chodil, K., Meyers, C., Irani, T., \& Baker, L. (2008, June). Branding the Land-Grant University: Agricultural Producers' and Community Leaders' Awareness of the Tripartite Mission. Paper presented at the Conference of the Association for Communication Excellence in Agriculture, Natural Resources, and Life and Human Sciences, Traverse City, MI.

Conrad, P. (1999). Use of expertise: Sources, quotes, and voice in reporting of genetics in the news.

Public Understanding of Science, 8 (4), 285-302.

Fill, C. (2002). Marketing Communications: Contexts, Strategies, and Applications. Harlow, England: Prentice Hall.

Desiere, S., \& Bey-Ling, S. (2007). Exploring the development of an organizational approach to media relationships. Public Relations Review, 33, 96-98.

Donnellan, L. M., \& Montgomery, F. S. (2005). Rethinking extension communications: Is issues programming the key? Journal of Extension, 43 (2).

Glaser, B. (1965). The constant comparative method of qualitative analysis. Social Problems, 12(4), 436-445.

Grunig, J. E., \& Grunig, L. A. (1992). Models of public relations and communications. In J. E. Grunig, Excellence in public relations and communication management (pp. 285-325). Mahwah, NJ: Lawrence Earlbaum Associates.

Grunig, J. E., \& Grunig, L. A. (1998). The relationship between public relations and marketing in excellent organizations: Evidence from the IABC study. Journal of Marketing Communications , 4 (3), 141-162.

Grunig, L. A. (1997). Excellence in public relations. In C. L. Caywood, The handbook of strategic public relations and integrated communications (pp. 286-300). New York: McGraw-Hill.

Hachigian, D., \& Hallahan, K. (2003). Perceptions of public relations web sites by computer. Public Relations Review, 29 (1), 43-62.

Hogan, M. (1994). Effective public relations in extension. Journal of Extension, 32 (3).

Irani, T., Ruth, A., Telg, R., \& Lundy, L. (2006). The Ability to Relate: Assessing the Influence of a Relationship Marketing Strategy and Message Stimuli on Consumer Perceptions of Extension. Journal of Extension, 44(6), available at: http://www.joe.org/joe/2006december/a7.shtml

Meyers, C., Irani, T., \& Eckhardt, E., (2006). Using focus groups to develop an Extension home horticulture public radio program. Journal of Applied Communications, 90(4), 39-54.

Schenkler, I., \& Herrling, T. (2003). Guide to media relations. Upper Saddle River, NJ: Pearson Education, Inc.

Kellogg Commission on the Future of State and Land-Grant Universities. (1999, February). Returning to our roots: The engaged institution. Retrieved January 10, 2008, from http://www. nasulgc.org/NetCommunity/Document.Doc?id=183

Ryan, M., \& Martinson, D. L. (1988). Journalists and public relations practitioners: Why the antagonism? Journalism Quarterly, 65, 131-140. 
Rasmussen, W. D. (1989). Taking the university to the people: The first seventy-five years. Ames: Iowa State University.

Telg, R., Irani, T., Hurst, A., Kistler, M. (2007, April). Local marketing and promotional efforts of Florida extension agents. Journal of Extension, 45(2), Article 2FEA5. Retrieved September 20, 2008, from http://www.joe.org/joe/2007April/a5.shtml

Warner, P. D., Christenson, J. A., Dillman, D. A., \& Salant, P. (1996). Public perception of Extension. Journal of Extension, 34(4). Retrieved January 10, 2007, from http://www.joe.org/ joe/1996august/a1.html 